\title{
Political Islam and Democracy
}

On 14 May 2008, the Center for the Study of Islam and Democracy (CSID) held its ninth annual conference, entitled "Political Islam and Democracy: What Do Islamists and Islamic Movements Want?" at the Marriot Renaissance Hotel. This event brought together a distinguished group of experts to discuss the relationship between religion and democracy, the Muslim Brotherhood and democratic evolution, negotiating and implementing democracy in diverse contexts, and other related topics.

The first session, which included Nelly Lahoud (professor of political theory, Goucher College), Mark Gould (professor of sociology, Haverford College), and Amr Hamzawy (senior associate, Carnegie Endowment for 
International Peace) raised such issues as dismissing the idea that Islam and democracy are mutually exclusive and discrediting the terrorists who have hijacked Islam and turned it into the very things it stands against: radicalism, closed-mindedness, intolerance, and violence. Gould discussed "Sovereignty of God: Constitutional Processes in Islam and Christianity," and Hamzawy delved into an analysis of the Brotherhood's draft party platform.

The second session investigated the Muslim Brotherhood, a highly debated and at times misunderstood Islamic organization found throughout the Arab world. The panel featured Radwan Ziadeh (senior fellow, U.S. Institute of Peace), Bahey eldin Hassan (Cairo Institute for Human Rights), Ibrahim el-Houdaiby (board member and columnist, the Egyptian Muslim Brotherhood's website www.Ikhwanweb.com), and Najib Ghadbian (associate professor of political science and Middle East studies, University of Arkansas). The panelists spoke on several critical issues, including the Muslim Brotherhood in Syria, the program of its "political party" from a human rights perspective, changes within the Egyptian chapter due to contextual changes between 2005 and 2007, and its positions toward democracy. This particularly intriguing session was broadcast live on Al-Jazeera News.

The luncheon and roundtable discussion was incredibly insightful and heated, due to such panelists as Carl Gershman (president, National Endowment for Democracy), Abderazzak Makri (founding member, Movement for a Society of Peace [MSP], Algeria; elected member of Parliament), Mohamed Yatim (deputy secretary general, Party of Justice and Development), and Joshua Muravchik (resident scholar, American Enterprise Institute; author of Exporting Democracy: Fulfilling America's Destiny [1991]). The two speakers from Morocco and Algeria stated most vehemently that Islam encourages and supports democracy and democratization, but that the modernization of traditional Islamic thought has been greatly suppressed by increasingly secular governments. At times, this reality has caused Islamic movements to lean toward radicalization due to their frustration with the regimes. Muravchik said that mixing religion too much with government may end up removing religion's higher moral and spiritual ground and restrict it within the confines of the mechanical nature of government.

The third session introduced three profound speakers: Anwar N. Haddam (president and co-founder, Movement for Liberty and Social Justice [MLJS], Algeria), Laurel Rapp (international education program manager, One Voice Movement), and Yusuf Fernandez (journalist and editor of two Muslim websites: www.webislam.com and www.revistaamanecer.com), who addressed democratization over the years in Algeria, Morocco, and Indonesia. Today, as Haddam explained, Muslim democrats throughout Algeria are working hard to rebuild the democracy to which they once came so close to achieving and 
to show the world that they desire all Algerians' prosperity and wellbeing. Rapp expounded on first-hand accounts of Moroccan women's integration in the political, economic, and social arenas, while Fernandez addressed the status of Islamic parties in Indonesia and Morocco and their support and desire for democracy, protection of human rights, and respect for the rule of law.

The fourth session focused primarily on the struggles to implement democracy fully in several Muslim countries, from Lebanon to the Maldives to post-Soviet Central Asia. Featured were Anthony C. Bowyer (program manager, Caucasus and Central Asia, International Foundation for Election Systems), Jonathan Upton (founding member, pro-democracy New Maldives faction), and Eric Bordenkircher (doctoral student, Islamic studies, University of California-Los Angeles). Topics discussed included "Islamic Movements and Democracy in Central Asia: Integration or Isolation," "The Maldives: Reform Deferred," and "Islamists and a Pluralist Society: Hezbollah and Jama ah al-Islamiyah's Cosociational Experience in Lebanon." It was clear that considerable international support, cooperation, and understanding is critical to ensure peaceful democratic transitions in all of these countries.

The conference culminated in the addresses of the three Banquet Dinner keynote speakers: Mohammed Ayoob (university distinguished professor of international relations, University of Michigan), Saad eddin Ibrahim (founder, Ibn Khaldoun Center, Cairo), and Francis J. Ricciardone (former ambassador of the United States to Egypt). Topics like "The Many Faces of Political Islam," "From Taliban to Erdogan," and refuting the notions that American policymakers "lump all Islamists into the category of terrorists and extremists" and that the United States has abandoned its rhetoric of pushing for democracy were analyzed.

The excitement of the 180 people in attendance spoke to the importance of the issues being raised and the necessity of engaging people of all backgrounds and expertise to find a common ground between Islam and democracy. Although there certainly are many obstacles to democracy in the Muslim world, it all needs to be kept in perspective. As Carl Gershman said during his address, "even when people comment on the problems - the backsliding, the fall-off in U.S. pressure for democracy - they are demonstrating that the issue [of democracy in the Arab and Muslim world] cannot be avoided." The pursuit of democracy in the Muslim world is destined to be a long and difficult path, but it is critical to remember that nothing worth having comes easily, and that establishing democracies in the Muslim world will, in the end, be well worth the effort.

Mariem Masmoudi Intern, Center for the Study of Islam and Democracy Washington, DC 